\title{
Crystal Structure of $\mathrm{Ca}_{2} \mathrm{Na}_{2}\left(\mathrm{CO}_{3}\right)_{3}$ (Shortite)
}

\author{
B. Dickens, A. Hyman, ${ }^{*}$ and W. E. Brown** \\ Institute for Materials Research, National Bureau of Standards, Washington, D.C. 20234
}

(December 18, 1970)

\begin{abstract}
$\mathrm{Ca}_{2} \mathrm{Na}_{2}\left(\mathrm{CO}_{3}\right)_{3}$ crystallizes in the orthorhombic unit cell $a=4.947(1) \mathrm{A}, b=11.032(2) \mathrm{A}$. and $c=7.108(1) \mathrm{A}$ at $25^{\circ} \mathrm{C}$ with two formula weights in space-group Amm2. The structure has been redetermined, corrected, and refined to $R_{w}=0.025, R=0.020$ using 684 "observed" x-ray reflections from a single crystal. Corrections were made for absorption and isotropic extinction. In the extinction refinements, $r$ refined to $0.00017(1) \mathrm{cm}$. The structure consists of $\mathrm{Ca}_{2} \mathrm{NaCO}_{3}$ layers interleaved with $\mathrm{Na}\left(\mathrm{CO}_{3}\right)_{2}$ layers. The $\mathrm{Ca}$ ion is coordinated strongly to nine oxygens, including three $\mathrm{CO}_{3}$ edges, with $\mathrm{Ca} . . . \mathrm{O}$ distances varying from $2.401(2) \AA$ to $2.576(2) \mathrm{A}$. One $\mathrm{Na}$ ion is coordinated strongly to eight oxygens, including two $\mathrm{CO}_{3}$ edges, with $\mathrm{Na}$. . . O distan es from 2.429(2) $\AA$ to 2.605(1) $\AA$. The other $\mathrm{Na}$ ion is coordinated strongly to six oxywens, including one $\mathrm{CO}_{3}$ edge, at $2.296(1) \mathrm{A}$ to $2.414 \mathrm{~A}$. and weakly to a seventh at 3.050(3) A. One $\mathrm{CO}_{3}$ group is coordinated to seven cations, the other is coordinated to eight. The $\mathrm{CO}_{3}$ groups have seemingly maximized their edge sharing with $\mathrm{Ca}$ ions rather than $\mathrm{Na}$ ions.
\end{abstract}

Key words: Calcium sodium carbonate; crystal structure; shortite; single-crystal x-ray diffraction.

\section{Introduction}

As part of a program of studies $[1,2]^{1}$ to obtain precise structural parameters on calcium carbonates, calcium carbonate hydrates, calcium phosphates, and related compounds, we have reinvestigated the crystal structure of $\mathrm{Ca}_{2} \mathrm{Na}_{2}\left(\mathrm{CO}_{3}\right)_{3}$, which exists in nature as the mineral shortite. The structural features in these compounds are important in the consideration of possible epitaxial, syntaxial, and substitutional solid solution relationships in the major inorganic phases found in vivo.

Shortite was first found [3] in a matrix of montmorillonite clay which also contains pyrite $\left(\mathrm{FeS}_{2}\right)$, calcite $\left(\mathrm{CaCO}_{3}\right)$, and a carbonate of magnesium in crystals which were too small to be identified. Massive deposits of the commercially important mineral trona $\left(\mathrm{Na}_{2} \mathrm{CO}_{3}\right.$. $\mathrm{NaHCO}_{3} \cdot \mathrm{H}_{2} \mathrm{O}$ ) are also found in the vicinity. A crystal structure for shortite has been reported by Wickman [4], who suggested atomic positions on the basis of refractive indices, spatial considerations, and the intensities of the $0 \mathrm{kl}$ reflections. We found this structure to contain one incorrect feature. The corrected structure of shortite is reported here.

\section{Data Collection and Structure Refinement}

The crystal used in the data collection is an approximate sphere, radius $0.112(4) \mathrm{mm}$, ground from a shortite

*Department of Chemistry, University of Maryland Baltimore County, Baltimore, Md. **Director. American Dental Association Research Program. National Bureau of Standards, Washington, D.C. 20234.

1 Figures in brackets indicate the literature references at the end of this paper. fragment from mineral sample 105807, National Museum of Natural History, Smithsonian Institution, Washington, D.C. (sample supplied by J. S. White, Jr.). The sphere was mounted on the goniometer head in our usual way [2].

formula (ideal): $\mathrm{Ca}_{2} \mathrm{Na}_{2}\left(\mathrm{CO}_{3}\right)_{3}$

cell: orthorhombic

$$
\begin{aligned}
& a=4.947(1) \AA \\
& b=11.032(2) \AA \\
& c=7.108(1) \AA
\end{aligned}
$$

volume $=387.9 \AA^{3}$

space-group Amm2;

cell contents $2\left[\mathrm{Ca}_{2} \mathrm{Na}_{2}\left(\mathrm{CO}_{3}\right)_{3}\right]$

reciprocal lattice extinctions: $k+l=2 n+1$ for $h k l$;

calculated density $2.620 \mathrm{~g} \cdot \mathrm{cm}^{-3}$;

observed density $2.629 \mathrm{~g} \cdot \mathrm{cm}^{-3}[3]$.

The procedure given in reference [2] was followed in the collection and processing of data with the following exceptions. The $\theta-2 \theta$ scans were carried out at $2 \%$ min. Each background was counted for 20 s. 1659 reflections were collected from the $h k l$ and $\bar{h} k l$ octants and were merged into a unique set of 711 , of which 684 are "observed" and 27 are "unobserved." The $R$ factor between observed equivalent reflections was 0.01 . No absorption corrections were made because the maximum error in an intensity due to absorption is 0.8 percent. For $\mathrm{Ca}_{2} \mathrm{Na}_{2}\left(\mathrm{CO}_{3}\right)_{3}, \mu(\mathrm{Mo})=15.7 \mathrm{~cm}^{-1}$. The Picker ${ }^{2}$ hardware dropped the least significant

2 Certain commercial equipment, instruments, or materials are identified in this paper in order to specify the experimental procedure adequately. In no case does such identification imply recommendation or endorsement by the National Bureau of Standards, nor does it imply that the material or equipment identified is necessarily the best available for the it imply 
digit during the data collection so that the standard deviations from counting statistics, and consequently our assessment of whether a given reflection is observed or unobserved, is only marginally correct. This affects very few reflections in the present case because the sample scattered strongly and nearly all reflections were unequivocally "observed" (modified hardware was used in later investigations). $\sigma(F)$ was defined as $F / 10$ for $F<10$; 1 for $10<F<43$; and $F / 43$ for $F>43$, where $F_{\max }$ was 211 ; weights in the least-squares refinements were $1 / \sigma^{2}$. Wickman's structure [4] for $\mathrm{Ca}_{2} \mathrm{Na}_{2}\left(\mathrm{CO}_{3}\right)_{3}$ would not refine to a residual, $R_{w}$, below 0.3. Examination of the Patterson function and an $F_{0}$ electron density Fourier synthesis phased from structure factor calculations using the positions of the $\mathrm{Ca}$ and $\mathrm{Na}$ ions suggested new positions for the $\mathrm{C}(1)$ and $\mathrm{O}(1)$ atoms. This structure was refined isotropically to $R_{w}=0.056, R=0.050$, and anisotropically to $R_{w}=0.030, R=0.023$ and then to $R_{w}=0.025$, $R=0.020$ with refinement on the isotropic extinction parameter, $r$, in addition to the previously varied parameters. The least-squares program RFINE written by Finger [5] was used. Only observed reflections were used in these refinements. The scattering factors for the neutral atoms were taken from Cromer and Mann [6]. No corrections for anomalous dispersion were made. The final value of $r$ is $0.00017(1) \mathrm{cm}$ where $F^{2}=F_{\text {unc }}^{2}\left(1+\beta r\left|F_{\text {unc }}\right|^{2}\right)^{1 / 2}$ and $F_{\text {unc }}$ is the structure factor uncorrected for extinction. The notation is that of Zachariasen [7]; here $r$ may be related to the average domain size if the crystal is of type II where the extinction is assumed to be governed by spherical domains. The $z$ coordinate of Ca was set equal to zero to define the origin along $c$. In the final cycle, the average shift/error was 0.01 and the standard deviation of an observation of unit weight,

$$
\left[\Sigma W\left(F_{0}-F_{c}\right)^{2} /(711-50)\right]^{1 / 2},
$$

was 0.45 .

The highest peaks in an electron density difference synthesis calculated at $R=0.03$ corresponded to about 0.1 of an electron. The largest correlation coefficients are $0.42-0.44$ between the scale factor and the $B_{11}$, $B_{22}$, and $B_{33}$ temperature factors of $\mathrm{Ca}$ and 0.64 be- tween the extinction parameter and the scale factor. All other correlation coefficients are less than 0.28.

The atomic parameters are given in table 1 . All atoms but $\mathrm{O}(2)$ lie in special positions; the Wyckoff symbol and symmetry of these positions are given in table 1. The observed and calculated structure factors, uncorrected for extinction, are given in table 2 .

\section{Description of the Structure}

The structure of $\mathrm{Ca}_{2} \mathrm{Na}_{2}\left(\mathrm{CO}_{3}\right)_{3}$ is shown in figures 1 and 2. There are $\mathrm{Ca}_{2} \mathrm{NaCO}_{3}$ layers at $x=0.5$ and $\mathrm{Na}\left(\mathrm{CO}_{3}\right)_{2}$ layers at $x=0$. The $\mathrm{CO}_{3}$ group containing $\mathrm{C}(2), \mathrm{O}(3), \mathrm{O}(4)$, and $\mathrm{O}\left(4^{\prime}\right)$ lies on the mirror at $x=0.5$ and is a member simultaneously of three cation-anion chains in which cations are coordinated to edges and opposite apexes of the $\mathrm{CO}_{3}$ group. One $\mathrm{CaCO}_{3}$ chain runs parallel to [011], one runs parallel to [011], and one $\mathrm{NaCO}_{3}$ chain runs parallel to [001]. Similar cationanion chains are present in the barytocalcite phase of $\mathrm{BaCa}\left(\mathrm{CO}_{3}\right)_{2}$ [8]. The bonding of the apex of the $\mathrm{CO}_{3}$ group in the $\mathrm{NaCO}_{3}$ chain to $\mathrm{Na}$ is weak, however. The $\mathrm{CO}_{3}$ group containing $\mathrm{C}(1), \mathrm{O}(1), \mathrm{O}(2)$, and $\mathrm{O}\left(2^{\prime}\right)$, which is on the mirror at $x=0$ and has its plane parallel to (011) or (011), forms $\mathrm{NaCO}_{3}$ chains like those cation-anion chains at $x=0.5$. The two oxygens $\mathrm{O}(2)$ and $\mathrm{O}\left(2^{\prime}\right)$, which lie above and below the mirror, provide bonding with cations in neighboring $\mathrm{Ca}_{2} \mathrm{Na}\left(\mathrm{CO}_{3}\right)$ layers. Each $\mathrm{Na}$ at $x=0$ is common to two chains. The $\mathrm{CO}_{3}$ groups have seemingly oriented themselves to maximize edge coordination to $\mathrm{Ca}$; each $\mathrm{CO}_{3}$ group is bonded edgewise to two $\mathrm{Ca}$ ions and one Na ion. Preferential edge coordination of $\mathrm{CO}_{3}$ to $\mathrm{Ca}$ is in accord with $\mathrm{Ca}$ exerting the largest electrostatic attraction on the $\mathrm{CO}_{3}$ group and is consistent with the $\mathrm{Ca}$ coordinations in $\mathrm{CaCO}_{3}$. $6 \mathrm{H}_{2} \mathrm{O}$ [1], $\mathrm{CaNa}_{2}\left(\mathrm{CO}_{3}\right)_{2} \cdot 5 \mathrm{H}_{2} \mathrm{O}$ [9], and $\mathrm{CaNa}_{2}\left(\mathrm{CO}_{3}\right)_{2}$. $2 \mathrm{H}_{2} \mathrm{O}[9]$.

There is a void in the structure centered at about $0,0.5,0.8$ (figs. 1 and 2). If the ionic radius of the oxygen in the $\mathrm{CO}_{3}$ groups is assumed to be $1.4 \AA$, this void is about $2.2-2.5 \AA$ in diameter. Because it has both cations and anions in its surface, it is unlikely that it would be occupied, except perhaps by an inert gas atom.

TABLE 1. Atomic parameters of $\mathrm{Ca}_{2} \mathrm{Na}_{2}\left(\mathrm{CO}_{3}\right)_{3}$

\begin{tabular}{|c|c|c|c|c|c|c|c|c|c|c|}
\hline Atoms & $\left({ }^{\prime \prime}\right)$ & $x$ & $y$ & $z$ & $B_{11}^{*}$ & $B_{22}$ & $B_{33}$ & $B_{12}$ & $B_{13}$ & $B_{23}$ \\
\hline $\mathrm{Ca}$ & $e, m, 4$ & 0.5 & $0.21659(4)$ & 0.0 & $0.65(1)$ & $0.48(1)$ & $0.58(1)$ & & & $-0.01(1)$ \\
\hline $\mathrm{Na}(1)$ & $a, m m, 2$ & 0.0 & 0.0 & $0.9263(3)$ & $1.27(6)$ & $0.97(5)$ & $1.54(6)$ & & & \\
\hline $\mathrm{Na}(2)$ & $b, m m, 2$ & 0.5 & 0.0 & $0.6122(3)$ & $1.15(5)$ & $0.69(5)$ & $1.15(5)$ & & & \\
\hline $\mathrm{C}(1)$ & $d, m, 4$ & 0.0 & $0.2961(2)$ & $0.1697(3)$ & $0.57(6)$ & $0.84(7)$ & $0.64(5)$ & & & $-0.04(5)$ \\
\hline $\mathrm{O}(1)$ & $d, m, 4$ & 0.0 & $0.1985(2)$ & $0.0742(3)$ & $1.08(6)$ & $1.35(7)$ & $1.44(7)$ & & & $-0.81(6)$ \\
\hline $\mathrm{O}(2)$ & $f, 1,8$ & $0.2261(3)$ & $0.3456(1)$ & $0.2152(2)$ & $0.59(4)$ & $1.02(4)$ & $1.08(4)$ & $-0.19(3)$ & $-0.04(3)$ & $-0.02(3)$ \\
\hline $\mathrm{C}(2)$ & $b, m m, 2$ & 0.5 & 0.0 & $0.2253(5)$ & $1.1(1)$ & $0.58(8)$ & $0.64(9)$ & & & \\
\hline $\mathrm{O}(3)$ & $b, m m, 2$ & 0.5 & 0.0 & $0.0415(4)$ & $1.7(1)$ & $0.60(7)$ & $0.61(7)$ & & & \\
\hline $\mathrm{O}(4)$ & $e, m, 4$ & 0.5 & $0.1013(2)$ & $0.3111(3)$ & $2.10(7)$ & $0.57(5)$ & $0.99(6)$ & & & $-0.23(5)$ \\
\hline
\end{tabular}

Figures in parentheses are standard errors in last significant figure quoted, and were computed in the final cycle of full-matrix leastsquares refinement.

"Wyckoff symbol, site symmetry, and multiplicity of site in space-group Amm2.

*Thermal parameters have the form $\exp \left(-1 / 4\left(a^{* 2} B_{11} h^{2}+b^{* 2} B_{22,2} k^{2}+c^{* 2} B_{33} l^{2}+2 a^{*} b^{*} B_{12} h k+2 a^{*} c^{*} B_{13} h l+2 b^{*} c^{*} B_{13} k l\right)\right)$. 
ind

$\begin{array}{rrrrr}6 & 211 & 211 & 55 \\ 8 & 177 & 175 & 833 \\ 10 & 251 & 261 & 30 \\ 12 & 161 & 159 & 891\end{array}$

$0.1 \cdot \mathrm{L}$

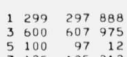

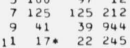

0.2 .4

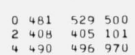

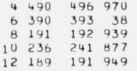

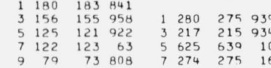

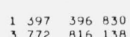

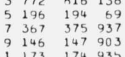

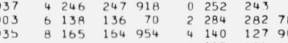

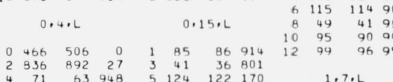

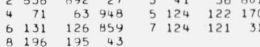

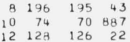

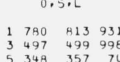

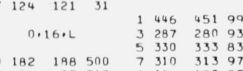

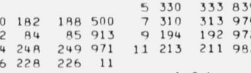

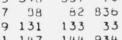

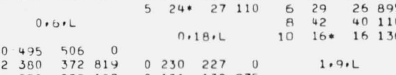

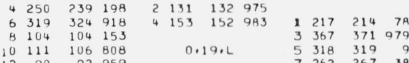

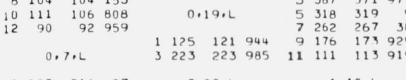

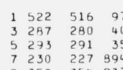

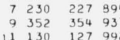

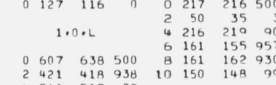

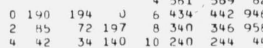

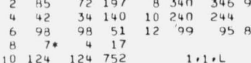

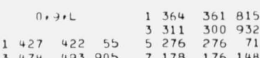

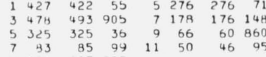

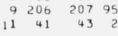

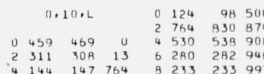

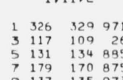

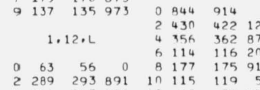

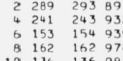

$\begin{array}{cccc} & 11,13,2 \\ 1 & 90 & 85 & 11 \\ 3 & 123 & 123 & 42\end{array}$

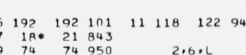

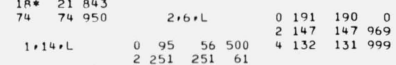

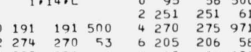

$2,19 \cdot \mathrm{L}$

$3,0.0$

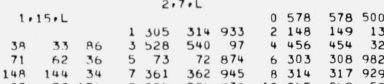

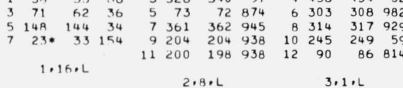

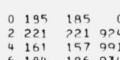

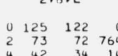

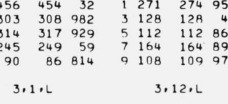

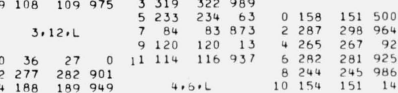

$\begin{array}{cccc}1 & 102 \\ 3 & 107 & 97 & 30 \\ 3 & 37 & 36 & 854 \\ 5 & 110 & 111 & 854\end{array}$

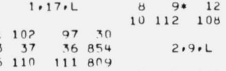

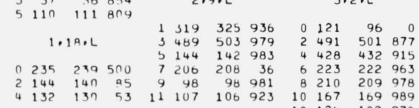

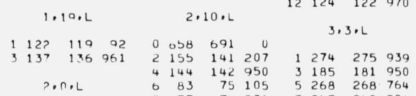

124.2297

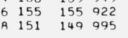

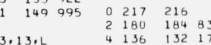

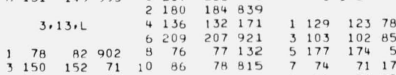

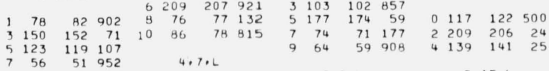

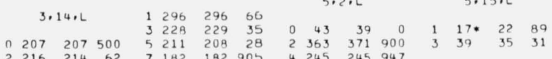

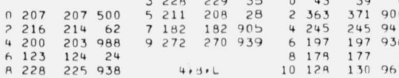

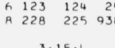

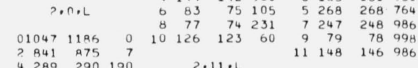

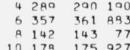

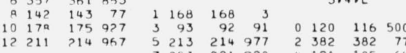

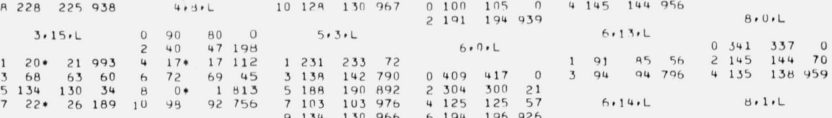

$3.16 . \mathrm{L}$

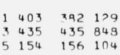

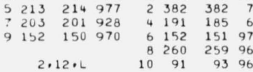

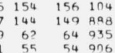

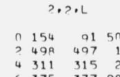

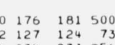

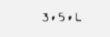

(..9. L

5.4 .2

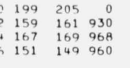

3.17.

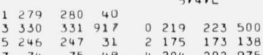

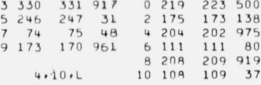

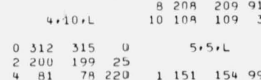

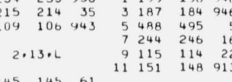

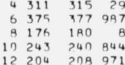

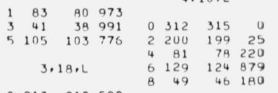

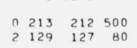

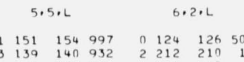

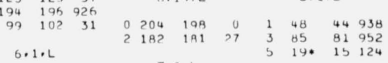

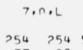

0.2 .2

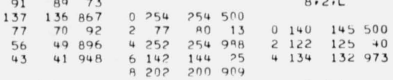

$\begin{array}{lllllllll} & \\ 0\end{array}$

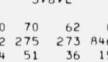
$12780 \quad 4,11, \mathrm{~L}$

$\begin{array}{llll}1 & 131 & 140 & 945 \\ 3 & 130 & 130 & \text { B7 } \\ 5 & 143 & 1146 & 954 \\ 5 & 143 & 954\end{array}$

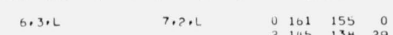

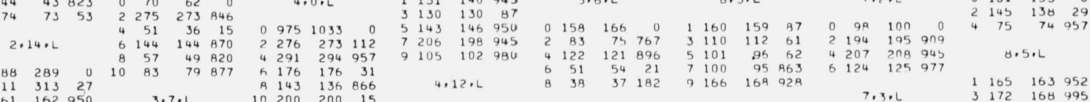

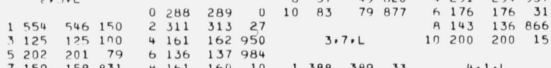

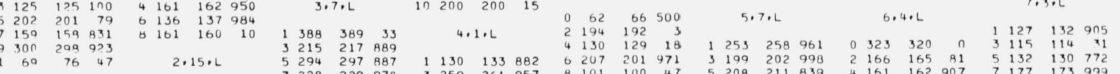

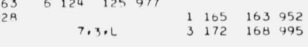

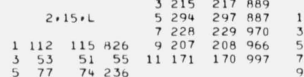

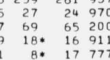

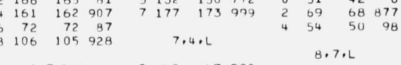

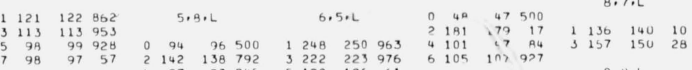

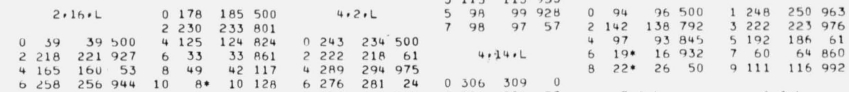

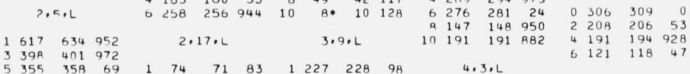

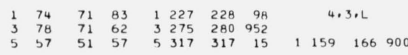

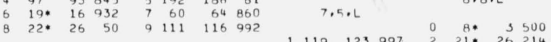

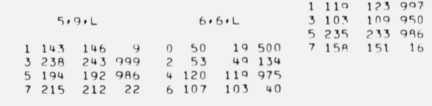

Columns are $\ell, 10 F_{0}, 10 F_{c}$ and phase in millicycles. "Unobserved" reflections are marked by $*$. The $F_{c}$ values do not include corrections for extinction. $F_{0}$ and $F_{c}$ are on an absolute scale.
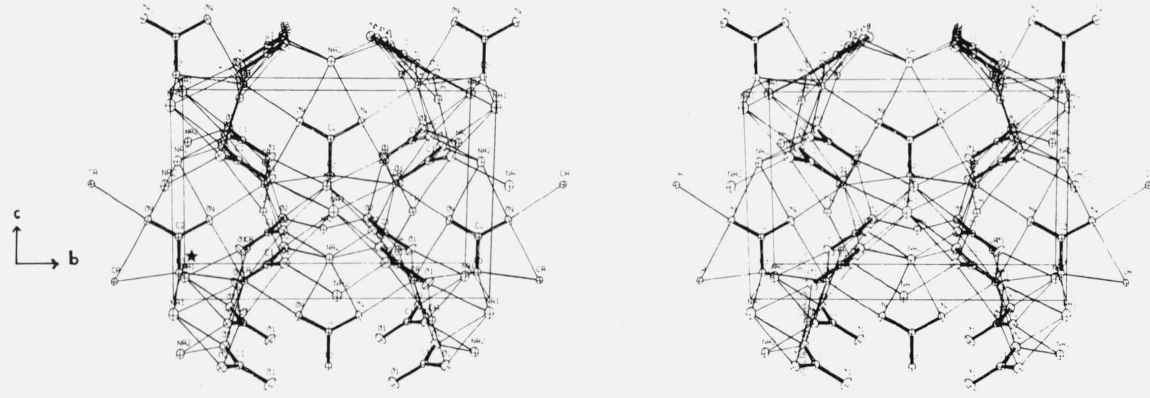

FIGURE 1. The crystal structure of $\mathrm{Ca}_{2} \mathrm{Na}_{2}\left(\mathrm{CO}_{3}\right)_{3}$, shortite, viewed along $\mathrm{a}$. The origin of the coordinate system is marked by * 

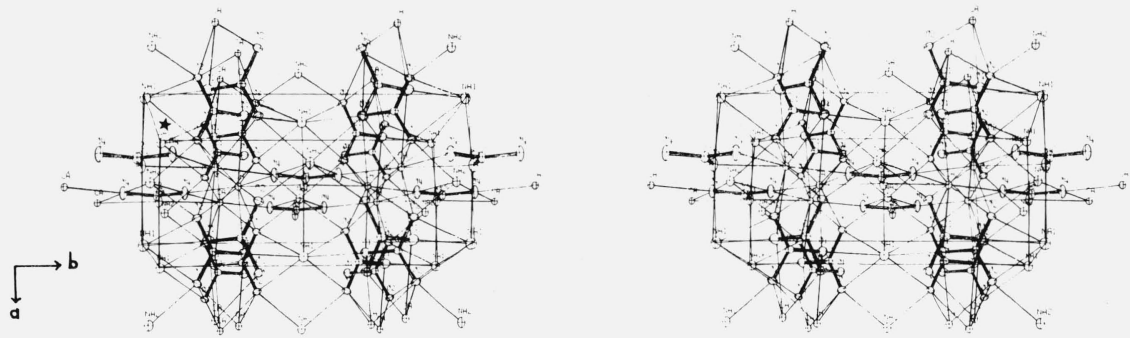

Figure 2. As in figure 1 but viewed along $\mathrm{c}$.

\subsection{The Calcium Ion Environment}

The $\mathrm{Ca}$ ion lies on a mirror plane at $x=0.5$. Its environment is shown in figure 3 and summarized in table 3 . The coordination contains three $\mathrm{CO}_{3}$ edges, $\mathrm{O}\left(1^{\mathrm{I}}, 2^{\mathrm{I}}\right), \mathrm{O}(1,2)$ and $\mathrm{O}(3,4)$, and three $\mathrm{CO}_{3}$ apexes, $\mathrm{O}\left(2^{\mathrm{II}}\right), \mathrm{O}\left(2^{\mathrm{III}}\right)$ and $\mathrm{O}\left(4^{\mathrm{I}}\right)$. The $\mathrm{Ca} \ldots \mathrm{O}$ distances indicate strong ionic bonding from $\mathrm{Ca}$ to all these oxygen atoms and are in the normal range. Strong coordination to nine neighboring oxygens is rare for $\mathrm{Ca}$ and is possible here because of the small $\mathrm{O}$... O separation $(\sim 2.2 \mathrm{~A})$ in the edge of the $\mathrm{CO}_{3}$ group. A large coordination number for $\mathrm{Ca}$ is favored by the $\mathrm{Ca}$... O interaction being the strongest electro-

TABLE 3. The calcium environment in $\mathrm{Ca}_{2} \mathrm{Na}_{2}\left(\mathrm{CO}_{3}\right)_{3}$

\begin{tabular}{l|c}
\hline \hline \multicolumn{1}{c|}{ Atoms } & Distance \\
& $\AA$ \\
$\mathrm{Ca}, \mathrm{O}(4)$ & $\AA$ \\
$\mathrm{Ca}, \mathrm{O}(3)$ & $2.401(2)$ \\
$\mathrm{Ca}, \mathrm{O}\left(2,2^{1}, 2^{\prime \prime}, 2^{\text {III) }}\right)$ & $2.411(1)$ \\
$\mathrm{Ca}, \mathrm{O}\left(1,1^{1}\right)$ & $2.508(1)$ \\
$\mathrm{Ca}, \mathrm{O}\left(4^{1}\right)$ & $2.543(1)$ \\
& $2.576(2)$ \\
\hline
\end{tabular}

In all tables of interatomic distances and angles, the quantities in parentheses are standard errors in the last significant figure and were computed from the standard errors in the atomic positional parameters and in the cell parameters. They include contributions from the variance co-variance matrix. The atom labels refer to atoms in figure 3 . static attraction in the crystal. The $\mathrm{Ca}$ ions are about $4 \AA$ apart in the structure; the shortest $\mathrm{Ca}$. . . Na distance, with associated weaker electrostatic repulsion than $\mathrm{Ca}$. . . Ca, is about $3.5 \mathrm{~A}$.

\subsection{The Na lon Environments}

There are two crystallographically distinct $\mathrm{Na}$ ions in the crystal structure. $\mathrm{Na}(2)$ and $\mathrm{Ca}$ lie in the same plane perpendicular to [100]. $\mathrm{Na}(1)$ lies halfway between the planes containing $\mathrm{Na}(2)$ and $\mathrm{Ca}$. Both $\mathrm{Na}$ ions lie at the intersections of mirror planes.

$\mathrm{Na}(1)$ is coordinated (fig. 3 and table 4) to eight oxygen atoms, of which $\mathrm{O}\left(2^{\mathrm{III}}, 2^{\mathrm{IV}}\right)$ and $\mathrm{O}\left(2^{\mathrm{V}}, 2^{\mathrm{VI}}\right)$ are $\mathrm{CO}_{3}$ edges. All the $\mathrm{Na}(1)$. . O distances are within the normal range and indicate strong ionic bonding. The coordination is similar to that of (i) the Ca ion $\mathrm{CaNa}_{2}\left(\mathrm{CO}_{3}\right)_{2}$. $5 \mathrm{H}_{2} \mathrm{O}[9]$, where the oxygens not in shared edges are in water molecules, and (ii) the $\mathrm{Ca}(1)$ ion in $\mathrm{Ca}_{5}$ $\left(\mathrm{PO}_{4}\right)_{2} \mathrm{SiO}_{4}[10]$.

TABLE 4. The sodium environments in $\mathrm{Ca}_{2} \mathrm{Na}_{2}\left(\mathrm{CO}_{3}\right)_{3}$

\begin{tabular}{l|c}
\hline \multicolumn{1}{c|}{ Atoms } & Distance \\
\hline & $A$ \\
$\mathrm{Na}(1), \mathrm{O}\left(1,1^{\mathrm{I}}\right)$ & $2.429(2)$ \\
$\mathrm{Na}(1), \mathrm{O}\left(2^{\mathrm{III}}, 2^{\mathrm{IV}} \cdot 2^{\mathrm{V}} \cdot 2^{\mathrm{VI}}\right)$ & $2.530(2)$ \\
$\mathrm{Na}(1), \mathrm{O}\left(3,3^{\prime}\right)$ & $2.605(1)$ \\
& \\
$\mathrm{Na}(2), \mathrm{O}\left(2^{\mathrm{II}}, 2^{\prime \prime \prime}, 2^{\mathrm{VI}}, 2^{\mathrm{VII}}\right)$ & $2.296(1)$ \\
$\mathrm{Na}(2), \mathrm{O}\left(4,4^{\prime}\right)$ & $2.414(3)$ \\
$\mathrm{Na}(2), \mathrm{O}(3)$ & $3.050(3)$ \\
\hline
\end{tabular}

The atom labels refer to atoms in figure 3 .

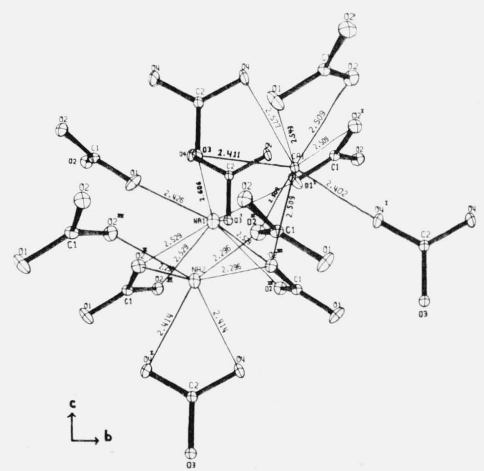

Figure 3. The $\mathrm{Ca}$ and $\mathrm{Na}$ environments in $\mathrm{Ca}_{2} \mathrm{Na}_{2}\left(\mathrm{CO}_{3}\right)_{3}$. The primes refer to atoms in tables 3 and 4 . 
$\mathrm{Na}(2)$ is bonded strongly to six oxygen atoms (table 4) essentially arranged in a square pyramid with a $\mathrm{CO}_{3}$ shared edge $\mathrm{O}\left(4,4^{\mathrm{I}}\right)$ centered about the apex position (fig. 3). The environment of $\mathrm{Na}(2)$ is completed by $\mathrm{O}(3)$, which is, however, $3.050 \AA$ away and thus bonded relatively weakly to $\mathrm{Na}(2)$. The geometry of strong coordination for $\mathrm{Na}(2)$ is like that of $\mathrm{Na}(2)$ in $\mathrm{Na}_{2} \mathrm{CO}_{3} \cdot \mathrm{H}_{2} \mathrm{O}$ [11].

\subsection{The $\mathrm{CO}_{3}$ Groups and Their Environments}

The dimensions of the $\mathrm{CO}_{3}$ groups are given in table 5. The $\mathrm{C}(1) \mathrm{CO}_{3}$ group is nearly trigonal with an average $\mathrm{C}-\mathrm{O}$ distance of $1.282 \AA$; the $\mathrm{C}(2) \mathrm{CO}_{3}$ group appears to be significantly non-trigonal, but with an average $\mathrm{C}-\mathrm{O}$ distance of $1.283 \AA$. The average $\mathrm{C}-\mathrm{O}$ distances compare well with $1.283(2) \AA$ in calcite $\left(\mathrm{CaCO}_{3}\right)$ [12], $1.285 \AA$ in aragonite $\left(\mathrm{CaCO}_{3}\right)$ [2], $1.286 \AA$ in $\mathrm{Na}_{2} \mathrm{CO}_{3} \cdot \mathrm{H}_{2} \mathrm{O}$ [11], $1.288 \AA$ in $\mathrm{CaNa}_{2}\left(\mathrm{CO}_{3}\right)_{2} \cdot 5 \mathrm{H}_{2} \mathrm{O}$ [9], $1.286 \AA$ in $\mathrm{CaNa}_{2}\left(\mathrm{CO}_{3}\right)_{2} \cdot 2 \mathrm{H}_{2} \mathrm{O}$ [9], and $1.286 \AA$ in $\mathrm{CaCO}_{3} \cdot 6 \mathrm{H}_{2} \mathrm{O}[1]$. All these distances are uncorrected for thermal motion.

The environments of the $\mathrm{CO}_{3}$ groups are shown in figure 4 and are summarized in table 5 . All three edges of both $\mathrm{CO}_{3}$ groups are coordinated, in both cases to two $\mathrm{Ca}$ ions and one $\mathrm{Na}$ ion in the same plane as the $\mathrm{CO}_{3}$ group. All oxygen atoms are further coordinated: $\mathrm{O}(1)$ to $\mathrm{Na}(1)$ in the plane of the $\mathrm{C}(1) \mathrm{CO}_{3}$ group, $\mathrm{O}(2)$ to $\mathrm{Ca}$ and $\mathrm{Na}(2)$ both out of this plane, $\mathrm{O}(4)$ to $\mathrm{Ca}(1)$ in the plane of the $\mathrm{C}(2) \mathrm{CO}_{3}$ group, and $\mathrm{O}(3)$ to two $\mathrm{Na}(1)$ ions which are both out of this plane. Edge coordination of $\mathrm{O}(3,4)$ and $\mathrm{O}\left(3,4^{\mathrm{I}}\right)$ to $\mathrm{Ca}$ is expected to decrease the $\mathrm{O}(3)-\mathrm{C}(2)-\mathrm{O}(4)$ and $\mathrm{O}(3)-\mathrm{C}(2)-\mathrm{O}\left(4^{\mathrm{I}}\right)$ angles in accord with Pauling's rule because the $\mathrm{O}\left(4,4^{\mathrm{I}}\right)$ edge of the same $\mathrm{CO}_{3}$ group is coordinated with weaker electrostatic force to $\mathrm{Na}(2)$. This is in accord with the observed $\mathrm{O}-\mathrm{C}-\mathrm{O}$ angles of $118.7(2)^{\circ}$ for the $\mathrm{Ca}$ coordinated edges and $122.7(4)^{\circ}$, for the $\mathrm{Na}$ coordinated edge. Similar effects would be expected in the other $\mathrm{CO}_{3}$ group, where $\mathrm{O}(1,2)$ and $\mathrm{O}\left(1,2^{1}\right)$ are coordinated to $\mathrm{Ca}$ and $\mathrm{O}\left(2,2^{1}\right)$ is coordinated to $\mathrm{Na}$. Here the angles, 119.6(1) for the Ca coordinated edges and 120.9(2) for the $\mathrm{Na}$ coordinated edge are in the right directions from $120^{\circ}$, but are more nearly equal, which suggests that the effect is more complex than this simple reasoning. The average of the distances $\mathrm{Ca} \ldots \mathrm{O}(3)$ and $\mathrm{Ca} \ldots \mathrm{O}(4)$ is $2.493 \AA$; that of the Ca . . O $(1)$ and
TABle 5. The Carbonate Anions and Their Environments $\mathrm{Ca}_{2} \mathrm{Na}_{2}\left(\mathrm{CO}_{3}\right)_{3}$

\begin{tabular}{|c|c|}
\hline Atoms & $\begin{array}{l}\text { Distance, A, } \\
\text { or angle deg. }\end{array}$ \\
\hline $\begin{array}{l}\mathrm{C}(1), \mathrm{O}(1) \\
\mathrm{C}(1), \mathrm{O}\left(2,2^{1}\right) \\
\mathrm{O}(1), \mathrm{O}\left(2,2^{1}\right) \\
\mathrm{O}(2), \mathrm{O}\left(2^{\mathrm{l}}\right) \\
\mathrm{O}(1), \mathrm{C}(1), \mathrm{O}\left(2,2^{1}\right) \\
\mathrm{O}(2), \mathrm{C}(1), \mathrm{O}\left(2^{1}\right)\end{array}$ & $\begin{array}{l}1.273(3) \AA \\
1.286(2) \\
2.211(2) \\
2.238(2) \\
119.6(1)^{\circ} \\
120.9(2)\end{array}$ \\
\hline $\begin{array}{l}\mathrm{C}(2), \mathrm{O}(3) \\
\mathrm{C}(2), \mathrm{O}\left(4,4^{\mathrm{\prime}}\right) \\
\mathrm{C}(3), \mathrm{O}\left(4,4^{\mathrm{I}}\right) \\
\mathrm{O}(4), \mathrm{O}\left(4^{\mathrm{I}}\right) \\
\mathrm{O}(3), \mathrm{C}(2), \mathrm{O}\left(4,4^{\mathrm{I}}\right) \\
\mathrm{O}(4), \mathrm{C}(2), \mathrm{O}\left(4^{\mathrm{I}}\right)\end{array}$ & $\begin{array}{l}1.306(4) \AA \\
1.273(3) \\
2.218(3) \\
2.235(4) \\
118.7(2)^{\circ} \\
122.7(3)\end{array}$ \\
\hline $\begin{array}{l}\mathrm{O}(1), \mathrm{Na}\left(1^{1}\right) \\
\mathrm{O}(1), \mathrm{Ca}, \mathrm{Ca}^{\prime}\end{array}$ & $\begin{array}{l}2.429(2) \AA \\
2.543(1)\end{array}$ \\
\hline $\begin{array}{l}\mathrm{O}(2), \mathrm{Na}(2) \\
\mathrm{O}(2), \mathrm{Ca}^{1 !} \\
\mathrm{O}(2), \mathrm{Ca}^{1 ! \prime} \\
\mathrm{O}(2), \mathrm{Na}(1) \\
\mathrm{O}(2), \mathrm{O}\left(2^{1 !}\right)\end{array}$ & $\begin{array}{l}2.296(1) \\
2.508(1) \\
2.508(1) \\
2.530(2) \\
2.709(2)\end{array}$ \\
\hline $\begin{array}{l}\mathrm{O}(3), \mathrm{Ca} \\
\mathrm{O}(3), \mathrm{Ca}^{1 \mathrm{I}} \\
\mathrm{O}(3), \mathrm{Na}(1), \mathrm{Na}\left(1^{\prime}\right) \\
\mathrm{O}(3), \mathrm{Na}(2)\end{array}$ & $\begin{array}{l}2.411(1) \\
2.411(1) \\
2.605(1) \\
3.050(3)\end{array}$ \\
\hline $\begin{array}{l}\mathrm{O}(4), \mathrm{Ca}^{11} \\
\mathrm{O}(4), \mathrm{Na}(2) \\
\mathrm{O}(4), \mathrm{Ca}\end{array}$ & $\begin{array}{l}2.401(2) \\
2.414(3) \\
2.576(2)\end{array}$ \\
\hline
\end{tabular}

The atom labels refer to atoms in figure 4.

$\mathrm{Ca} \ldots \mathrm{O}(2)$ distances is $2.526 \AA$. The difference of $0.03 \AA$ between these average values may account for part of the difference in angles of the $\mathrm{CO}_{3}$ groups because $\mathrm{O}(3)$ and $\mathrm{O}(4)$ are bonded more strongly to Ca and the $\mathrm{O}(3), \mathrm{C}(2), \mathrm{O}(4)$ angle would then be expected to be decreased more than the $\mathrm{O}(1), \mathrm{C}(1), \mathrm{O}(2)$ angle.

In the absence of hydrogen bonding, the oxygens coordinated most strongly to cations may be expected to have the longest $\mathrm{C}-\mathrm{O}$ bonds. This is qualitatively the case. Similar effects have been observed in $\mathrm{Na}_{2} \mathrm{CO}_{3}$. $\mathrm{H}_{2} \mathrm{O}$ [11], $\mathrm{CaNa}_{2}\left(\mathrm{CO}_{3}\right)_{2} \cdot 5 \mathrm{H}_{2} \mathrm{O}$ and $\mathrm{CaNa}_{2}\left(\mathrm{CO}_{3}\right)_{2} \cdot 2 \mathrm{H}_{2} \mathrm{O}$

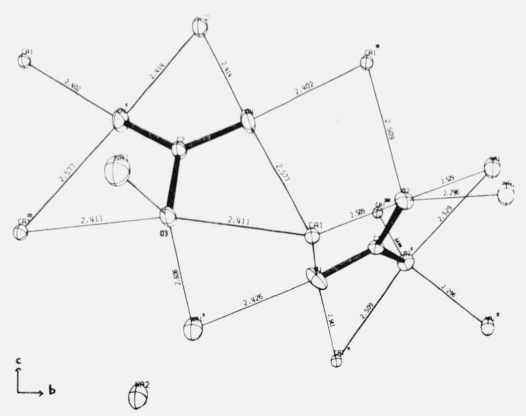

FIGURE 4. The environments of the $\mathrm{CO}_{3}$ groups in $\mathrm{Ca}_{2} \mathrm{Na}_{2}\left(\mathrm{CO}_{3}\right)_{3}$. The primes refer to atoms in table 5. 
[9] and in the $\mathrm{PO}_{4}$ groups in $\mathrm{Ca}_{7} \mathrm{Mg}_{9}(\mathrm{Ca}, \mathrm{Mg})_{2}\left(\mathrm{PO}_{4}\right)_{12}$ [13]. In the $\mathrm{C}(1) \mathrm{CO}_{3}$ group in $\mathrm{Ca}_{2} \mathrm{Na}_{2}\left(\mathrm{CO}_{3}\right)_{3}$, the bond distance $\mathrm{C}(1)-\mathrm{O}(2)$ and the symmetrically equivalent distance $\mathrm{C}(1)-\mathrm{O}\left(2^{1}\right)$ are slightly longer than $\mathrm{C}(1)-\mathrm{O}(1)$. $\mathrm{O}(2)$ is coordinated to two $\mathrm{Ca}$ ions and two $\mathrm{Na}$ ions; $\mathrm{O}(\mathrm{l})$ is coordinated to one $\mathrm{Ca}$ ion and one $\mathrm{Na}$ ion. In the $\mathrm{C}(2) \mathrm{CO}_{3}$ group, $\mathrm{C}(2)-\mathrm{O}(3)$ is appreciably longer than the two equivalent distances $\mathrm{C}(2)-\mathrm{O}(4)$ and $\mathrm{C}(2)-$ $\mathrm{O}\left(4^{\mathrm{I}}\right) . \mathrm{O}(3)$ is coordinated to two $\mathrm{Ca}$ ions and two $\mathrm{Na}$ ions; $\mathrm{O}(4)$ is coordinated to two $\mathrm{Ca}$ ions and one $\mathrm{Na}$ ion. The differences in the coordinations of $\mathrm{O}(3)$ and $\mathrm{O}(4)$ here do not appear large enough to explain the $0.035 \AA$ difference in $\mathrm{C}-\mathrm{O}$ bond lengths. The difference, $0.020 \AA$, in the bond lengths $C(1)-O(2)$ and $\mathrm{C}(2)-\mathrm{O}(3)$, may be partly explained by the fact that while the $\mathrm{C}(1) \mathrm{CO}_{3}$ group has two longer bonds, the $\mathrm{C}$ (2) $\mathrm{CO}_{3}$ group has only one, which may therefore be expected to have approximately twice the extension due to the cation field that the $\mathrm{C}(1)-\mathrm{O}(2)$ bonds have.

The $\mathrm{C}(1)$ atom in the $\mathrm{C}(1) \mathrm{CO}_{3}$ group is $0.012(3) \AA$ out of the plane defined by the $\mathrm{O}(1), \mathrm{O}(2)$, and $\mathrm{O}\left(2^{\mathrm{I}}\right)$ atoms. This may be a result of perturbation of the $s p^{2}$ hybridization of the oxygen atoms by neighboring cations. The $\mathrm{C}(2) \mathrm{CO}_{3}$ group is planar by symmetry.

\section{Discussion}

The positions given by Wickman, $(0.0,0.226,0.743)$ for $\mathrm{C}(1),(0.0,0.325,0.850)$ for $\mathrm{O}(1)$, and $(0.230,0.177$, $0.690)$ for $\mathrm{O}(2)$, which are $0.57,1.98$, and $0.31 \AA$, respectively, from the positions given here, show that in his structure the $\mathrm{C}(1) \mathrm{O}_{3}$ group has been reflected along $c$ through the plane $z=0.75$, so that $\mathrm{O}(1)$ then juts out into the void instead of being on the void surface. The interatomic distances are reasonable in Wickman's structure and the $\mathrm{O} \ldots \mathrm{O}$ repulsions are therefore approximately the same in the two models. In the structure reported here, however, $\mathrm{O}(1)$ is able to form stronger bonds to the two $\mathrm{Ca}$ ions above and below it along $a$, and to $\mathrm{Na}(1)$ in the same plane parallel to (100); this is probably the factor governing the orientation of the $\mathrm{CO}_{3}$ group. The calculation of refractive indices in the way originally given by Bragg [14] assumes that only oxygen atoms have optical anisotropy and ignores all interatomic interactions. Thus, Wickman, following this procedure, was able to obtain qualitative agreement between observed and calculated values using a model in which the orientation of the $\mathrm{C}(1) \mathrm{CO}_{3}$ group relative to the (001) plane was $\sim 35^{\circ}$ instead of $-31^{\circ} 42^{\prime}$. The average orientations of $\mathrm{C}(1) \mathrm{CO}_{3}$ groups in the unit cell are about the same for the two models when one takes into account the symmetry operations. This agreement can be seen from table 6 , which compares the observed indices with the values calculated for the two models using Bragg's procedure. A much more suitable test of these models, which would produce better quantitative agreement with the observed values, would require consideration of dipole-dipole coupling terms and optical anisotropy of all atoms, especially $\mathrm{Na}$, rather than just oxygens $[15,16]$. As a further refinement, the dependence of the atomic optical anisotropy on the environment should be incorporated.

\section{TABLE 6. Refractive indices for shortite}

\begin{tabular}{c|c|c|c}
\hline \hline Observed & $\begin{array}{c}\text { Wick- } \\
\text { man's } \\
\text { model }\end{array}$ & Here & $\begin{array}{c}\text { Orienta- } \\
\text { tion }\end{array}$ \\
\hline 1.531 & 1.515 & 1.502 & $c$ \\
1.555 & 1.545 & 1.541 & $a$ \\
1.570 & 1.555 & 1.554 & $b$ \\
\hline
\end{tabular}

J. S. Bowen collected the diffractometer data; P. B. Kingsbury used the ORTEP program of C. K. Johnson, Oak Ridge National Laboratory, to draw the figures. This investigation was supported in part by research grant DE-00572 to the American Dental Association from the National Institute of Dental Research and is part of the dental research program conducted by the National Bureau of Standards, in cooperation with the American Dental Association; the United States Army Medical Research and Development Command; the Dental Sciences Division of the School of Aerospace Medicine, USAF; the National Institute of Dental Research; and the Veterans Administration.

\section{References}

[1] Dickens, B., and Brown, W. E., The crystal structure of $\mathrm{CaCO}_{3} \cdot 6 \mathrm{H}_{2} \mathrm{O}$ at $\sim-120^{\circ} \mathrm{C}$, Inorg. Chem. 9, 480-486 (1970).

[2] Dickens, B., and Bowen, J. S., Refinement of the crystal structure of aragonite $\left(\mathrm{CaCO}_{3}\right)$, J. Res. Nat. Bur. Stand. (U.S.) (in press).

[3] Fahey, J. J., Shortite, a new carbonate of sodium and calcium, Am. Min. 24, 514-518 (1939).

[4] Wickman, F. E., The crystal structure of shortite, $\mathrm{Ca}_{2} \mathrm{Na}_{2}\left(\mathrm{CO}_{3}\right)_{3}$, Arkiv for Mineral. Geol. 1, 95-101 (1949).

[5] Finger, L. W., Determination of cation distribution by leastsquares refinement of single-crystal X-ray data, Carnegie Institute of Washington Year Book 67, 216-217 (1969).

[6] Cromer, D. T., and Mann, J. B., X-ray scattering factors computed from numerical Hartree Fock wave functions, Acta Cryst. A24, 321-324 (1968).

[7] Zachariasen, W. H., A general theory of X-ray diffraction in crystals, Acta Cryst. 23, 558-564 (1967).

[8] Dickens, B., and Bowen. J. S., A refinement of the crystal structure of $\mathrm{BaCa}\left(\mathrm{CO}_{3}\right)_{2}$ (barytocalcite). J. Res. Nat. Bur. Stand. (U.S.) (in press).

[9] Dickens, B., and Brown, W. E., The crystal structures of $\mathrm{CaNa}_{2}\left(\mathrm{CO}_{3}\right)_{2} \cdot 5 \mathrm{H}_{2} \mathrm{O}$, synthetic gaylussite, and $\mathrm{CaNa}_{2}\left(\mathrm{CO}_{3}\right)_{2}$. $2 \mathrm{H}_{2} \mathrm{O}$, synthetic pirssonite, Inorg. Chem. 8, 2093-2103 (1969).

[10] Dickens, B., and Brown, W. E., The crystal structure of $\mathrm{Ca}_{5}\left(\mathrm{PO}_{4}\right)_{2} \mathrm{SiO}_{4}$ (silico-carnotite), Tschermaks Mineral. und Petrog. Mitteilungen (in press). 
[11] Dickens, B., Mauer, F. A., and Brown, W. E., A refinement of the crystal structure of $\mathrm{Na}_{2} \mathrm{CO}_{3} \cdot \mathrm{H}_{2} \mathrm{O}$, J. Res. Nat. Bur. Stand. (U.S.), 74A. (Phys. and Chem.), 319-324 (1970).

[12] Chessin, H., Hamilton, W. C., and Post, B., Position and thermal parameters of oxygen atoms in calcite, Acta Cryst. 18, 689-693 (1965).

[13] Dickens, B., and Brown, W. E., The crystal structure of $\mathrm{Ca}_{7} \mathrm{Mg}_{9}(\mathrm{Ca}, \mathrm{Mg})_{2}\left(\mathrm{PO}_{4}\right)_{12}$, Tschermaks Mineral. und Petrog. Mitteilungen (in press).
[14] Bragg, W. L., The refractive indices of calcite and aragonite, Proc. Roy. Soc. A105, 370-386 (1924).

[15] Lawless. W. N., and Devries, R. C.. Oxygen polarizability and point-dipole theory in the carbonate minerals, J. Phys. Chem. Solids 25. 1119-1124 (1964).

[16] Davis, T. A., and Vedam, K., Variation of the refractive indices of calcite, with pressure to 7 Kbar, Phys. Stat. Solids 26 , 285-290 (1968).

(Paper 75A2-656) 



\section{Publications of the National Bureau of Standards*}

\section{Selected Abstracts}

Berger, M. J., Seltzer, S. M., Bremsstrahlung and photoneutrons from thick tungsten and tantalum targets, Phys. Rev. C, 2 , No. 2, 621-631 (August 1970).

Key words: Bremsstrahlung; bremsstrahlung efficiency; Monte Carlo; photon neutron; radiation transport; thick targets.

Monte Carlo calculations have been made of electron-photon cascades in thick tungsten targets bombarded by electrons with energies up to $60 \mathrm{MeV}$. The following information has been obtained: (1) the bremsstrahlung efficiency, (2) the angular distribution of the emitted bremsstrahlung intensity, (3) the spectra of the bremsstrahlung emitted in various directions, (4) the transmission of primary and secondary electrons through the target, (5) energy deposition as function of the depth in the target, (6) the differential photon tracklength distribution inside the target, and (7) the yield of photoneutrons. The paper also includes various comparisons with experimental data.

Block, S., Weir, C. E., Piermarini, G. J., Polymorphism in benzene, napthalene, and anthracene at high pressure, Science 169, 586-587 (August 7, 1970).

Key words: Anthracene; benzene; high-pressure; naphthalene; polymorphism.

High-pressure optical observations using a microscope with the diamond-anvil pressure cell have (1) confirmed that there is a transition in naphthalene and no triple point to $500^{\circ} \pm 15^{\circ} \mathrm{C}$, (2) shown that there is a corresponding high-pressure transition in anthracene and no triple point to $550^{\circ} \pm 15^{\circ}$, (3) shown that a second reversible high-pressure form of benzene exists with a triple point (liquid-II-III) at $590^{\circ} \pm 15^{\circ}$ and approximately 40 kbars, and (4) demonstrated that, at approximately $500^{\circ}$ for anthracene, $550^{\circ}$ for naphthalene and $600^{\circ}$ for benzene III, these materials transform irreversibly to deep reddish-orange colored products which have not yet been characterized.

Bowen, R. L., Crystalline dimethacrylate monomers, .J. Dental Res. 49, No. 4,810-815 (July-August 1970).

Key words: Dimethacrylates; thermosetting monomers; ternary eutectic; urification methods: resins for composites; phthalate monomers; biomaterials.

Certain dimethacrylate monomers can be prepared and purified by recrystallization. Upon mixing, the crystals liquify by forming a ternary eutectic. The colorless oily liquid is suitable for use in composite formulations.

Ensign. T. C., Chang. Te-Tse, Kahn, A. H., Hyperfine and nuclear quadrupole interactions in copper-doped TiO., Phys. Rev. 188, No. 2, 703-709 (Dec. 10, 1969).

Key words: Copper; EPR; $g$-factors: hyperfine interaction; quadrupole coupling: rutile: titanium dioxide.

Single crystals of $\mathrm{TiO}_{2}: \mathrm{Cu}^{2+}$ have been investigated at $20 \mathrm{~K}$ using the technique of electron paramagnetic resonance. The major features of the EPR spectra can be attributed to divalent copper $\left(3 d^{9}\right)$ in substitutional $\left(\mathrm{Ti}^{++}\right)$sites. Information has been gained about both isotopes of copper and about the interactions which concern this ion. For the substitutional site the spin Hamiltonian pa- rameters in the $\mathrm{S}=1 / 2, \mathrm{I}=3 / 2$ manifold are: $g_{x}=2.109, g_{y}=2.094$, $g_{z}=2.346, \quad \mathrm{~A}_{x}^{6.3}=+18.7 \times 10^{-4} \quad \mathrm{~cm}^{-1} . \quad \mathrm{A}_{y}^{63}=+27.2 \times 10^{-4} \quad \mathrm{~cm}^{-1}$, $\mathrm{A}_{z}^{6.3}=-87.5 \times 10^{-4} \mathrm{~cm}^{-1}, \mathrm{~A}_{. r}^{6.5}=+18.8 \times 10^{-4} \mathrm{~cm}^{-1}, \mathrm{~A}_{y}^{6.5}=+28.7 \times 10^{-4}$ $\mathrm{cm}^{-1}, \mathrm{~A}_{z}^{6.5}=-93.7 \times 10^{-4} \mathrm{~cm}^{-1}, \mathrm{P}_{x}=-2.56 \times 10^{-4}, \mathrm{P}_{y}=-2.37 \times 10^{-4}$, $P_{z}=+4.93 \times 10^{-4} \mathrm{~cm}^{-1}$. The magnitudes and relative signs of these parameters have been determined experimentally while the absolute signs have been predicted theoretically from a model which gives a consistent picture of the ordering of the $d^{9}$ electronic states. In addition, the theoretical treatment gives a satisfactory estimate of P. Departure from tetragonality was taken into account. The covalency parameter $\alpha^{2}$ which measures the fraction of the hole wave function on the $\mathrm{Cu}^{2+}$ is found to be 0.71 , and $\kappa$, the factor giving rise to isotropic hyperfine structure, is found to be 0.31 .

Ensign, T. C., Stokowski, S. E., Shared holes trapped by charge defects in SrTiO ${ }_{3}$, Phys. Rev. B, 1, No. 6, 2799-2810 (March 15, 1970).

Key words: Color centers; EPR; hole centers; optical absorption; shared holes: $\mathrm{SrTiO}_{3}$.

Using the techniques of EPR and optical irradiation in conjunction with optical absorption measurements, we have gained useful information about the nature of some hole centers in $\mathrm{SrTiO}_{3}$. Primarily we have investigated single crystals doped with aluminum at temperatures near $77 \mathrm{~K}$. Two principal centers have been explored: (1) the $\mathrm{Al}^{-} \mathrm{O}^{-}$center - a hole shared among the oxygens which surround $\mathrm{Al}^{3+}$, and $(2)$ the $\mathrm{X}-\mathrm{O}^{-}$center - a hole shared in a similar fashion. but more deeply trapped by a charge defect of unknown origin. The $\mathrm{Al}-\mathrm{O}^{-}$center arises after band gap irradiation and is characterized at $77 \mathrm{~K}$ by the following $g$-values and hyperfine constants: $g_{\|}=2.0137, g_{1}=2.0124, \mathrm{~A}_{\|}=8.3 \times 10^{-4} \mathrm{~cm}^{-1}$, and $\mathrm{A}_{+}=$ $7.6 \times 10^{-4} \mathrm{~cm}^{-1}$. The $\mathrm{X}-\mathrm{O}^{-}$center is present before optical irradiation. No hyperfine structure is observed, but the isotropic $g$-value is 2.0130 at all temperatures from 4.2 to $300 \mathrm{~K}$. An $800 \mathrm{~nm}$ absorption band arising after band gap excitation has been correlated with the Al- $\mathrm{O}^{-}$center. 430 and $600 \mathrm{~nm}$ absorption bands have been correlated with the absence of $\mathrm{Fe}^{3+}$ in the EPR spectrum, and a $500 \mathrm{~nm}$ band has also been observed. In addition, the role of iron in the photochronic processes of $\mathrm{SrTiO}_{3}$ is presented. Finally, theoretical work utilizing the molecular orbital $\sigma$ and $\pi$ states in $\mathrm{O}_{\mathrm{h}}$ symmetry has provided a firm basis for the sharing model. The experimental $g$ values and hyperfine constants are discussed in light of this mode! and are found to be in good agreement.

Estin. A. J., Editor. Precision measurement and calibration. Selected NBS Papers on electricity-radio frequency, Nat. Bur. Stand. (U.S.), Spec. Publ. 300, Vol. 4, 456 pages (./une 1970) \$5.50, SD Catalog No. C13.10:300/v.4.

Key words: Admittance; antenna; attenuator: bolometer; calorimetry: horn; impedance: interferometry; measuring system: phase: power; radiometry: resonant cavity; voltage; waveform; waveguide junction.

This volume is one of an extended series which brings together some of the previously published papers, monographs, abstracts, and bibliographies by NBS authors dealing with the precision measurement of specific physical quantities and the calibration of the related metrology equipment. The contents have been selected as being useful to the standards laboratories of the United States in tracing to NBS standards the accuracies of measurement needed for research work, factory production, or field evaluation. 
Volume 4 contains reprints through June 1967 on radio-frequency electrical measurements covering the following topics: Power, Sinusoidal Voltage and Current, Electromagnetic Fields and Antennas, Radar and Baseband Pulses, Noise, Attenuation and Phase, Impedance, Radio Frequency Materials, Quasi-optics and Millimeter Waves, and Applications to Measurement Systems.

Furcolow, W. H., Technical Standards Coordinator, Mosaic-parquet hardwood slat floorinw, Nat. Bur. Stand. (U.S.), Voluntary Prod. Stand. 27-70, 13 pages (Sept. 1970), 25 cents, SD Catalog No. C1.3.20/2:27-70.

Key words: Flooring; hardwood flooring; mosaic-parquet flooring: slat flooring.

This Voluntary Product Standard covers requirements for grading. moisture content. dimensions, construction, and finish for mosaicparquet hardwood slat flooring which is intended for use in residential. institutional, and commercial buildings. A method for marking and labeling to indicate compliance with the Standard is also provided. Manufacturers' recommendations on ordering and installation are included in an appendix. The Standard does not cover flooring squares or blocks which are fabricated from conventional tongue and groove type strips.

Goldstein. J. I., Henderson. E. P.. Yakowitz, H., Investigation of lunar metal particles (Proc. Apollo 11 Lunar Science Conf., January 1970, Houston, Texas). Ceochim. Cosmochim. Acta 1, 499-512 (1970).

Key words: Electron probe microanalysis; lunar samples; lunar simulation: lunar thermal history; meteorites: probe microanalysis: scanning electron microscopy.

Several metallic particles from lunar fine samples 84 and $85-17 \mathrm{M}$ and from breccia sample 46-18A were investigated by means of optical microscopy, scanning electron microscopy and electron probe microanalysis. These particles consisted of two large globules, metal spread on glassy spheres, splinters and metal in the foamy pumicelike fragments. The largest globule had a structure consisting of 40 $\mu \mathrm{m} \mathrm{Fe}-\mathrm{Ni}$ dendrites in a matrix of troilite. A high $\mathrm{Ni}$ rim was found at the troilite-dendrite interface. The dendrites showed typical Ni segregation, the composition at the outside being about $16 \mathrm{w} / \mathrm{o} \mathrm{Ni}$ with $13 \mathrm{w} / \mathrm{o} \mathrm{Ni}$ at the center. The troilite contained 0.1 to $1.5 \mathrm{w} / \mathrm{o}$ $\mathrm{Ni}$ and appears to be in dis-equilibrium. The rim contains 29 to 46 $\mathrm{w} / \mathrm{O} \mathrm{Ni}$ and about $0.3 \mathrm{w} / \mathrm{o} \mathrm{S}$. The rim is a $\gamma$ phase in the $\mathrm{Fe}-\mathrm{Ni}-\mathrm{S}$ system and was created by the rejection of Ni from the troilite. We were able to synthesize this globule; the same structure was obtained. From this simulation, the cooling rate was determined as $2.5^{\circ} \mathrm{C} / \mathrm{sec}$. This globule probably was created by the impact of a chondrite on the moon.

A globule separated from the breccia rock apparently solidified quickly and then cooled slowly, the rock acting as a kind of crucible. This globule's metal regions contain $2 \mathrm{w} / 0 \mathrm{Ni}, 1 \mathrm{w} / \mathrm{o}$ P. $0.3 \mathrm{w} / \mathrm{o}$ Co. balance $\mathrm{Fe}$. There are also phosphide eutectic regions containing fine intergrowths of kamacite. troilite and carbides. This particle shows a striking simularity to spheroids from the Canyon Diablo iron. The evidence indicates that this globule was probably created by the impact of an iron meteorite on the moon.

The analysis of the metal particles makes it clear that both meteoritic and lunar $\mathrm{Fe}-\mathrm{FeS}$ intergrowth are present in the lunar fines. The lunar metal is similar to the meteoritic material in that it is surrounded by sulfide: both metal constituents are of comparable size. structure and Co content. The two types of material can be differentiated by the significant $\mathrm{Ni}$ and $\mathrm{P}$ content of the transformed original meteoritic material.

Holt, H. K., Theory of gas lasers and its application to experiment, Phys. Rev. A, 2, No. I, 23.3-249 (.July 1970).

Key words: Collisions: gas laser; line widths: power output: theory: tuning curves.

The semi-classical theory of gas lasers has been reformulated using rate equations to describe the density matrix time behavior. The solution to these equations, in the form of a Fourier series, is applicable to arbitrarily high laser intensities. A calculation of the effect of phase-changing collisions is also included. The results are compared to experimental data taken with a He-Ne laser operating at a wavelength of $1.15 \mu \mathrm{m}$.

Klein, R., A field emission study of carbon monoxide on h.c.p. metals rhenium and ruthenium, Surface Sci. 20, No. $l, l-17$ (March 1970).

Key words: Carbon monoxide: desorption: field emission: monoxide: rhenium, ruthenium, surface migration.

The surface migration, work function increments, and desorption of carbon monoxide on two h.c.p. metals, rhenium and ruthenium. were observed with field emission techniques. Carbon monoxide is weakly bound to ruthenium and more strongly bound to rhenium. For a complete monolayer, the work function increment is $1.3 \mathrm{eV}$ for ruthenium and 0.8 for rhenium. Surface migration commences at a readily observable rate at about $125 \mathrm{~K}$ for ruthenium and shows both boundary and boundary free characteristics. Rhenium has an ill defined surface migration temperature region because the desorption precedes and overlaps it. Two well defined binding states for $\mathrm{CO}$ on rhenium are seen.

Ledbetter, H. M., Reed, R. P., On the martensite crystallography of Fe-Ni alloys, Mater. Sci. Eng. 5, No. 6, 341-349 (.) /une 1970).

Key words: Crystallographic theory: iron-nickel alloy; martensite.

For the first time lattice parameter data and habit plane measure ments are available for an alloy system whose crystallographic features change continuously with composition. This information has been produced for the plate-like martensitic transformation in Febase alloys containing between 29 and $35 \mathrm{wt}$ \% Ni. This paper presents a critical examination of the data from the viewpoint of the theories of martensite crystallography. It is found that the current theories cannot explain the variation of the habit plane with composition without invokin a varyin $\delta(1.000$ to 1.013$), \delta$ being an isotropic dilatation parameter. In addition to the habit plane, several quantities have been calculated as a function of composition: the volume change, the magnitude of the lattice invariant deformation, the masnitude and direction of the shape change, and the orientation relationship. The effects of errors in lattice parameter and of thermal expansion are considered.

Mann, W. B., Garfinkel, S. B., Editors, Radioactivity calibration standards, Nat. Bur. Stand. (U.S.), Spec. Publ. 331, l20 pages (August 1970) \$1.25, SD Catalog No. C13.10:331.

Key words; Alpha-particle standards; calibration consistency; coincidence counting; decay-scheme effects: efficiency tracing; gammaray standards: international comparisons: liquid-scintillation counting; radionuclide half-lives; radionuclide standards.

Experimental procedures and methods used in nine international radioactivity standardization laboratories are described by eight authors. The possibility of attainirg accuracies of the order of 0.01 percent are discussed. The desirability of carrying out consistency checks of gamma-ray standards with time, using a $4 \pi \gamma$ ionization chamber is emphasized. The validity of radioactivity standards is examined. International comparisons organized by the Bureau International des Poids et Mesures are discussed. An analogue method of liquid-scintillation counting is described. Certain types of radioactivity standards are criticized. The fields of interest of the two Canadian laboratories are discussed. Details of the work in progress at the Boris Kidric Institute and National Bureau of Standards are presented.

Milligan, D. E., Jacox, M. E., Spectra of radicals in Physical Chemistry, 4, Chapter 5, 19.3-2.31 (Academic Press Inc., New York, N.Y., 1970).

Key words: Electronic spectrum; flash photolysis; free radicals: matrix isolation: molecular orbitals: vibrational spectrum.

Problems arising in the direct spectroscopic detection of free radicals are surveyed. Apparatus used for the spectroscopic study of free radicals in the gas phase and trapped in inert solid matrices is 
described. The advantage and limitations of flash photolysis and of matrix isolation studies for the production and detection of free radicals are considered. Examples of radicals studied by these techniques are cited, and dat on the structure and chemical bonding of these species derived from the observed spectra are correlated with the predictions of simple molecular orbital theory.

Reimann, C. W., Santoro, A., Mighell, A. D., The crystal molecular structure of hexapyrazolenickel(II) nitrate, $\mathrm{Ni}\left(\mathrm{C}_{3} \mathrm{H}_{4} \mathrm{~N}_{2}\right)_{6}$ $\left(\mathbf{N O}_{3}\right)_{2}$, Acta Cryst. B26, Part 5, 521-526 (May 1970).

Key words: Inorganic coordination complex: octahedral coordination; pyrazole; trigonal symmetry; $\mathrm{x}$-ray structure determination.

The crystal structure of hexapyrazolenickel(II) nitrate, $\mathrm{Ni}\left(\mathrm{C}_{3} \mathrm{H}_{4} \mathrm{~N}_{2}\right)_{6}$ $\left(\mathrm{NO}_{3}\right)_{2}$, was determined by single-crystal diffraction techniques. Crystals of $\mathrm{Ni}\left(\mathrm{C}_{3} \mathrm{H}_{4} \mathrm{~N}_{2}\right)_{6}\left(\mathrm{NO}_{3}\right)_{2}$ are trigonal with $a=9.958, c=7.278 \AA$, space group $=\mathrm{P} \overline{3}, Z=1, \rho_{0}=1.57 \mathrm{~g} . \mathrm{cm}^{-3}, \rho_{c}=1.57 \mathrm{~g} . \mathrm{cm}^{-3}$. Threedimensional counter data were collected (1115 reflections) and the structure was solved by an analysis of the Patterson map. The complex cation, $\mathrm{Ni}\left(\mathrm{C}_{3} \mathrm{H}_{4} \mathrm{~N}_{2}\right)_{6}^{+}$, formed by the coordination of six planar pyrazole molecules to the nickel ion, has $\overline{3}$ point symmetry. The nickel ion lies at the center of a nearly regular octahedron of coordinated nitrogen atoms. These complex cations and nitrate anions are linked by hydrogen bonds between each pyrrole type nitrogen atom $(\mathrm{N}-\mathrm{H})$ in the pyrazole ring and an oxygen atom in the nitrate group. The final refinement by full matrix anisotropic least-squares analysis resulted in an $R$ value of 0.053 .

Ruff, A. W.. Jr., Measurement of stacking fault energy from dislocation interactions, Met. Trans. 1, No. 9, 2391-241.3 (Sept. 1970).

Key words: Dislocations; dislocation nodes; dislocation ribbons faulted dislocation dipoles; stacking fault energy: stacking fault tetrahedra.

The theories and methods applied to the determination of the stack ing fault energy $(\gamma)$ using techniques of direct observation of disloca tion configurations are reviewed. The four principal methods, utilizing dislocation nodes, multiple ribbons, stacking fault tetrahedra, and faulted dipoles, are discussed in detail. Different theoretical treatments are compared wherever possible. Experimenta procedures and quantitative measurement methods are reviewed. Detailed examples of the application of each method are given. For $\gamma / \mu b$ in the range of $2 \times 10^{-4}$ to $5 \times 10^{-3}$ ( $\mu$ the shear modulus, $b$ the Burgers vector), measurements on dislocation nodes or multiple ribbons in favorable cases should permit determinations of the stacking fault energy to a precision of 5 percent. For larger values of $\gamma / \mu b$ (up to $12 \times 10^{-3}$ ), measurements can be made on tetrahedra or faulted dipoles with less precision. Larger values of the stacking fault energy require high resolution studies of dislocations; these techniques are not yet well established. Possible sources of systematic bias are discussed. Two significant theoretical problems remain concerning the treatment of the dislocation core and the use of anisotropic elasticity. It is of prime importance to characterize as carefully as possible the materials studied if accurate results are desired.

Simson, B. G., Mandel, J., Brenner, F. C., Research for a uniform quality grading system for tires. III. Breaking energy, Rubber Chem. Tech. 43, No. 2, 356-369 (March 1970).

Key words: Bias ply; breaking energy; passenger car; radial; tire strength: tires; winter.

A test procedure, designed to classify tires according to their average breaking energy has been applied to a sample of passenger car tires. Data are reported on 127 different tires of all grades and types over a range of sizes.

A scaling system is devised and applied to the data. It is found that the system leads to conclusions similar to those derived from the original data.

Ugiansky, G. M., Skolnick, L. P., Stiefel, S. W., Directional effects in the stress corrosion cracking of an aluminum alloy, Corrosion 25, No. 2, 77-86 (February 1969).
Key words: Aluminum alloy; corrosion; directional effects; grain morphology; preferred orientation; stress corrosion.

Studies of the relative effects of grain morphology and preferred orientation on the directional susceptibility to intergranular stress corrosion cracking of a 7075-T651 aluminum alloy plate have been conducted. The role of grain morphology was found to be of paramount importance in controlling crack propagation. It was found that a slow rate of propagation along grain boundaries parallel to the applied stress, and the fact that the intergranular crack must propagate primarily in this direction accounts for the low susceptibility of longitudinally stressed specimens. The results suggest that the threshold stress for short transverse specimens approximates the low stress necessary to crack grain boundaries normal to the applied stress, and the threshold stress for longitudinal specimens approximates the high stress needed to propagate cracks along boundaries parallel to the applied stress. Preferred orientation was found to be of secondary importance when compared to the effect of grain morphology. A high degree of preferred orientation, rather than any specific slip plane orientation, was found to increase the susceptibility of specimens with the same grain morphology. Pitting corrosion was found to occur to a much greater extent on unstressed than on stressed (undergoing stress corrosion cracking) specimens. This phenomenon is explained by what is termed an "internal cathodic protection mechanism."

Wall, L. A., Flynn, J. H., Straus, S., Rates of molecular vaporization of linear alkanes, J. Phys. Chem. 74, 17, 32.37-3242 (1970).

Key words: Alkanes; heats; $n$-hexatricontane; $n$-pristane: $n$-tetracosane; $n$-tetranonacontane, vaporization

The rates of molecular vaporization of four linear alkanes, $n$-pristane $\left(\mathrm{C}_{19}\right)$, $n$-tetracosane $\left(\mathrm{C}_{34}\right), n$-hexatricontane $\left(\mathrm{C}_{36}\right)$, and $n$-tetranonacontane $\left(\mathrm{C}_{94}\right)$ was measured. By both isothermal and nonisothermal methods, the kinetics of the vaporization process showed essentially zero order behavior as a vaporization process proportional to the surface area should. The Arrhenius slope plus $3 R T / 2$ was compared to heats of vaporization of other $n$-alkanes in the literature. The old and new data show that the heat of vaporization is proportional to the two-thirds power of the number, $n$, of carbon atoms in the species and not to the first power. The majority of the known heats of vaporization were well fitted by the equation.

$$
\Delta H_{r}=13.43 n^{2 / 3}-0.08075 T+12.22, \mathrm{KJ} / \mathrm{mol}
$$

The tetranonacontane vaporized without detection of hydrocarbon decomposition products by mass spectral monitoring. The results suggests a much higher limit to the size of species capable of molecular vaporization without decomposition, than previously assumed.

West, E. D., Churney, K. I., Theory of isoperibol calorimetry for laser power and energy measurements, J. Appl. Phys. 41, No. 6, 2705-2712 (May 1970).

Key words: Calorimetry: laser calorimetry; lasers; thermadynamics.

I aser power and energy measurements are commonly made in calorimeters operating in a constant-temperature environment. These calorimeters are analyzed in terms of the first law of thermodynamics and the boundary value problem describing heat flow in the calorimeter. This theory of the measurement suggest design features of the calorimeter, sources of error to be avoided in design and operation, and tests to demonstrate experimentally the adequacy of the design. The analysis shows how time-temperature data can be used to allow for the temperature gradient on the calorimeter and the heat exchange due to transients in the temperature.

\section{Other NBS Publications}

J. Res. Nat. Bur. Stand. (U.S.), 74C (Eng. and Instr.), Nos. $3 \& 4$ (July-Dec. 1970), SD Catalog No. C13.22/sec.C:74/ 3\&4. \$1.25.

Techniques for comparing four-terminal-pair admittance standards. R. D. Cutkosky. 
Some applications for series impedance elements in radio frequency immittance measurements. L. E. Huntley.

A pulse heating method for the measurement of melting point of electrical conductors (thin wires) above $2000 \mathrm{~K}$. A. Cezairliyan.

A time-shared computer system for diffractometer control. H. A. Alperin and E. Prince.

Tensile deformation of vapor-deposited copper reinforced with tungsten wires. W. D. Jenkins, W. A. Willard, and D. A. Harne.

"Connector-pair" techniques for the accurate measurement of twoterminal low-value capacitances. A. Millea.

The use of dew-point temperature in humidity calculations. A. Wood.

Bolovac application for $\mathrm{HF}$ and microwave power measurement and standardization. M. C. Selby.

Publications of the National Bureau of Standards.

Index to volume 74C, January-December 1970.

Borie, E., Radiative corrections to back scattering, Phys. Rev. C, 2, No. 2, 770-771 (August 1970).

Candela, G. A., Spin relaxation process of chromium ion in potassium alum., J. Chem. Phys. 52, No. 7, 3754-3757 (April 1, 1970).

Evans, W., Garvin, D., The evaluator versus the chemical literature, J. Chem. Doc. 10, No. 3, 147-150 (1970).

Feldman, A., Brower, W. S., Jr., Horowitz, D., Optical activity and Faraday rotation in bismuth oxide compounds, Appl. Phys. Letters 16, No. 5, 201-202 (March 1, 1970).

Feldman, A., Kahn, A. H., Landau diamagnetism from the coherent states of an electron in a uniform magnetic field, Phys. Rev. B, 1, No. 12, 4584-4589 (June 15, 1970).

Frederikse, H. P. R., Comments on electronic transport in transition metal oxides, J. Res. Develop. 14, No. 3, 295-300 (May 1970).

Hosler, W. R., Low resistance contacts on semiconducting oxides, Solid-State Electron. 13, 517-519 (1970).

Howett, G. L., Achromatic-point prediction, J. Opt. Soc. Am. 60, No. 7,951-958 (July 1970).

Hubbell, J. H., X-ray absorption 75 years later, Phys. Bull. No. 21 , $353-357$ (1970).

Hummer, D. G., Mihalas, D., Model atmospheres for the central stars of planetary nebulae, Monthly Notices Roy. Astron. Soc. 147, No. 4, 339-354 (1970).

Hust, J. G., Thermal anchoring of wires in cryogenic apparatus, Rev. Sci. Instr. 41, No. 5, 622-624 (May 1970).

Johnson, W. T. K., Chertok, B. T., Dick, C. E., Study of nuclear states of several odd-A nuclei $68 \leqslant Z \leqslant 79$ through electromagnetic excitation from 2.3 to $3.6 \mathrm{MeV}$, Phys. Rev. Letters 25, No. 9, 599-602 (August 31, 1970).

Kasen, M. B., The effect of grain boundaries on the recovery of electrical properties during annealing, Scripta Met. 4, 575-580 (1970).

Mann, D. B., Roder, H. M., Liquefied natural gas as a cryogenic fluid-instrumentation and properties (Proc. Transmission Conf. American Gas Association Operation Section, New Orleans, La., May 26-27, 1969), pp. T-98-T-106 (American Gas Association, Arlington, Va., 1970).

Meijer, P. H. E., O'Keeffe, D. J., Low-temperature behavior of a pure dipole-dipole system, Phys. Rev. B, 1, No. 9, 3786-3800 (May 1, 1970).

Nimeroff, I., Deuteranopic convergence point, J. Opt. Soc. Am. 60, No. 7,966-969 (July 1970).
Phucas, C. B., Technical Standards Coordinator, Glass stopcocks with polytetrafluoroethylene (PTFE) plugs, Nat. Bur. Stand. (U.S.), Voluntary Prod. Stand. 28-70, 10 pages (Sept. 1970) 25 cents, SD Catalog No. C13.20/2:28-70.

Reed, R. P., Arp., V. D., Techniques for measuring stress, strain and resistivity at $4 \mathrm{~K}$ for very soft materials. Cryogenics Letter to Editor, 9, No. 5, 362-364 (October 1969).

Roder, H. M., Diller, D. E., Thermal conductivity of gaseous and liquid hydrogen, J. Chem. Phys. 52, No. 11, 5928-5949 (June 1, 1970).

Searles, S. K., Sieck, L. W., Ausloos, P., Reactions of ${ }_{-2} \mathrm{H}_{6}^{+}$. Formation of the $\left(\mathrm{C}_{2} \mathrm{H}_{6}\right)_{2}^{+}$ion, J. Chem. Phys. 53, No. 2, 849-850 (July 15, 1970).

Searles, S. K., Sieck, L. W., High pressure photoionization mass spectrometry, III. Reactions of $\mathrm{NO}^{+}\left(\mathrm{X}^{\prime} \Sigma^{+}\right)$with $\mathrm{C}_{3}-\mathrm{C}_{7}$ hydrocarbons at thermal kinetic energies, J. Chem. Phys. 53, No. 2, 794-797 (July 15, 1970).

Sharp, E. J., Weber, M. J., Cleek, G., Energy transfer and fluorescence quenching in Eu- and Nd-doped silicate glasses, J. Appl. Phys. 41, No. 1, 364-369 (Jan. 1970).

Shinyayev, A. Ya., Butrymowicz, D. B., Interdiffusion in and the phase diagram for vanadium-rich alloys of the $\mathrm{V}$-Al system at pressures 0 to 47 kbar, Met. Trans. 1, No. 7, 1905-1907 (July 1970).

Stein, P. G., Lipkin, L. E., Shapiro, H. M., Spectre II: Generalpurpose microscope input for a computer, Science 166, 328-333 (Oct. 17, 1969).

Straty, G. C., Prydz, R., The vapor pressure of liquid fluorine (Proc. 1969 Cryogenic Engineering Conf., June 16-18, 1969, Univ. of California, Los Angeles, Calif.), Chapter in Advances in Cryogenic Engineering 15, Paper No. B-1, 36-41 (Plenum Press, Inc., New York, N.Y., 1970).

Sugar, J., Spectrum of doubly ionized thulium (Tm III), J. Opt. Soc. Am. 69, No. 4, 454-466 (Apr. 1970).

Sugar, J., Configuration $4 f^{13} 5 d$ of doubly ionized ytterbium, J. Opt. Soc. Am. 60, No. 4, 571-572 (Apr. 1970).

Swartzendruber, L. J., Bennett, L. H., Clustering, cold work, and the Mïssbauer effect doublet structure in $\mathrm{Cu}-\mathrm{Ni}-\mathrm{Fe}$ alloys, Physics Letters 31A, No. 10, 581-582 (May 18, 1970).

Wilson, W. K., Fletcher, D. G., Paper research at the National Bureau of Standards, Indian Pulp Paper 24, No. 7, 325-329 (Jan. 1970).

Wolcott, N. M., Falge, R. L., Jr., Cluster specific heat in $\mathrm{Cu}_{0.6} \mathrm{Ni}_{0.4}$ alloy, J. Low Temp. Phys. 2, No. 314, 329-331 (1970).

Younglove, B. A., Measurements of the dielectric constant of saturated liquid oxygen (Proc. 1969 Cryogenic Engineering Conf. June 16-18, 1969, Univ. of California, Los Angeles, Calif.), Chapter in Advances in Cryogenic Engineering 15, Paper No. C-3, 70-75 (Plenum Press, Inc., New York, N.Y., 1970).

* Publications with prices and SD Catalog numbers indicated may be purchased directly from the Superintendent of Documents, U.S. Government Printing Office, Washington, D.C. 20402 (foreign: one-fourth additional). NBS nonperiodical series are also available from the National Technical Information Service (NTIS) Springfield, Va. 22151 (formerly the Clearinghouse for Federal Scientific and Technical Information). Reprints from outside journals and the NBS Journal of Research may often be obtained directly from the authors. 